\title{
USING A THREE-ISOTOPE BAYESIAN MIXING MODEL TO ASSESS THE CONTRIBUTION OF REFUSE DUMPS IN THE DIET OF YELLOW-LEGGED GULL LARUS MICHAHELLIS
}

\author{
UTILIZACIÓN DE UN MODELO DE MEZCLA BAYESIANO CON TRES \\ ISÓTOPOS PARA EVALUAR LA CONTRIBUCIÓN DE LOS VERTEDEROS \\ EN LA DIETA DE LA GAVIOTA PATIAMARILLA LARUS MICHAHELLIS
}

\author{
Aida Abdennadher ${ }^{1,2}$ *, Francisco Ramírez ${ }^{1,3}$, Mohamed Salah Romdhane ${ }^{2}$, \\ Lluis JOVER ${ }^{4}$ and Carolina SANPERA ${ }^{1}$
}

\begin{abstract}
Summary.- The yellow-legged gull Larus michahellis is usually considered as an opportunistic species that depends on food derived from anthropogenic activity, such as garbage and fishery discards. However, although it has become a problematic species in many Mediterranean countries, there is still no information about its status in Tunisia. The aim of this work was to assess the differential use of marine and terrestrial resources by the yellow-legged gulls breeding in an urban area on Chikly Island. Dietary reconstructions were performed through the analysis of regurgitates and $\delta^{13} \mathrm{C}, \delta^{34} \mathrm{~S}$ and $\delta^{15} \mathrm{~N}$ of fledgling's feathers. Contrary to most Mediterranean breeding colonies, and to our expectations, the mixing model showed that yellow-legged gulls from Chikly are above all marine foragers. Whereas the Lake of Tunis was the principal source of food in 2005 and 2007, chicks from 2006 were fed mainly with prey from the Gulf of Tunis. Although the Gulf is located further from the breeding colony and has less fishing activity than the Lake, our study demonstrated that it is used as an alternative foraging habitat. The Bayesian mixing model approach proved to be a useful tool for evaluating temporal variations in the feeding ecology of the colony, which is a relevant information for the management of a wild species. This study also demonstrated the importance of isotopic variability among years for inferring diet diversity and food availability for the colony, thereby allowing demographic forecasts when trophic resources vary in abundance or the foraging habitat is disturbed.
\end{abstract}

Key words: carbon, nitrogen, open air dump, regurgitates, seabirds, stable isotopes, sulfur, Tunisia.

1 Dept. Biologia Animal, Facultat de Biologia, Universitat de Barcelona, Diagonal 645, 08028 Barcelona, Spain.

2 Unité de Recherche (UR03AGRO) Aquatic Resources and Ecosystems Laboratory, Institut National Agronomique de Tunisie, Université de Carthage, 43 Avenue Charles Nicolle, 1082 TunisMahrajèn, Tunisia.

3 Estación Biológica de Doñana (EBD-CSIC), Dept. Conservation Biology, C/ Américo Vespucio s/n, 41092 Sevilla, Spain.

4 Dept. Salut Pública, Facultat de Medicina, Universitat de Barcelona, Casanova 143, 08036 Barcelona, Spain.

* Corresponding author: a.abdennadher@gmail.com 
RESUMEN._La gaviota patiamarilla Larus michahellis se considera una especie oportunista, que depende de los recursos alimenticios generados por la actividad humana, como son la basura de los vertederos o los descartes de pesca. A pesar de que la gaviota patiamarilla se ha vuelto problemática en varios países del Mediterráneo, no existe información sobre su estado en Túnez. Este trabajo ha tenido como objetivo estudiar el uso diferencial de las fuentes tróficas por la población de gaviota patiamarilla que cría en Chikly, una isla sometida a gran presión urbana. Para reconstruir su dieta, se ha llevado a cabo el análisis de regurgitados y de $\delta^{13} \mathrm{C}, \delta^{34} \mathrm{~S}$ y $\delta^{15} \mathrm{~N}$ en plumas de pollos. Al contrario de lo que esperábamos, teniendo como referencia lo que sucede en otras colonias del Mediterráneo, el modelo de mezcla ha demostrado que la alimentación de la gaviota patiamarilla de Chikly es principalmente marina. Mientras el lago de Túnez ha sido la mayor fuente alimentaria durante 2005 y 2007, el golfo de Túnez lo fue durante 2006. Aunque el golfo está más lejos del sitio de cría y en él se dé una menor actividad pesquera, nuestro estudio ha demostrado que sigue siendo una fuente alimentaria alternativa. El modelo de mezcla bayesiano ha resultado ser una herramienta con un gran potencial para evaluar los cambios en la ecología trófica de esta colonia a lo largo de los años, un punto clave para la correcta gestión de fauna salvaje. Por otro lado, cabe destacar la relevancia de la variabilidad temporal de las trazas isotópicas para inferir la diversidad y disponibilidad de los distintos recursos para la colonia, permitiendo así previsiones demográficas cuando estos varían en abundancia o debido a la alteración del hábitat.

Palabras clave: aves marinas, azufre, carbono, isótopos estables, nitrógeno, regurgitados, Túnez, vertedero.

\section{INTRODUCTION}

Several species of Laridae have shown high population growth in the Mediterranean Sea during recent decades. This increase is mainly explained by (1) their trophic plasticity and ability to use resources generated by human activity, and (2) the increasing availability of these anthropogenic resources over recent years (Bosch et al., 1994; Oro et al., 1995). The yellow-legged gull Larus michahellis has become regular in many coastal cities, where the abundance of open rubbish dumps and discards from the fishing activity provides significant food sources for this species (Duhem et al., 2007; Duhem et al., 2008; Sorace and Gustin, 2009). The yellow-legged gull population of the western Mediterranean has increased by $10 \%$ annually (Duhem et al., 2007; Thibault et al., 1996; Vidal et al., 1998). The Yellow-legged gull is becoming problematic in some localities because of its interaction with human activities such as aviation and agriculture, as well as its role in the transport of pathogens, and its predation on vulnerable and sensitive or protected species (Finney et al., 2001). The study of the trophic ecology of such a problematic species is key to understanding the demographic expansion of its populations and to defining adequate environmental management policies (Einoder, 2009). Conventional methods for dietary reconstruction, such as analysis of stomach contents, pellets or regurgitates, suffer from well-known limitations: notably, the time period over which dietary information can be inferred is short ( $<1$ day) and dietary estimation is biased towards bigger prey that are more resistant to digestion (Duffy and Jackson, 1986; González-Solís et al., 1997; Votier et al., 2003). Nevertheless, such conventional tools are still necessary for obtaining data about taxonomic dietary composition. Analysis of regurgitates yields more information than that of stomach contents because regurgitated food has been more recently consumed and is therefore less digested.

The analysis of naturally occurring stable isotopes of carbon $\left({ }^{13} \mathrm{C} /{ }^{12} \mathrm{C}\right.$, expressed as $\left.\delta^{13} \mathrm{C}\right)$, sulphur $\left({ }^{34} \mathrm{~S} /{ }^{32} \mathrm{~S}\right.$, expressed as $\left.\delta^{34} \mathrm{~S}\right)$ and 
nitrogen $\left({ }^{15} \mathrm{~N} /{ }^{14} \mathrm{~N}\right.$, expressed as $\left.\delta^{15} \mathrm{~N}\right)$ has become increasingly common in the study of the trophic ecology of particular populations (Bearhop et al., 2004; Cherel et al., 2005; Hobson et al., 1994; Hobson and Cherel, 2006) because it constitutes a relatively noninvasive way of obtaining time-integrated information on assimilated diets. Whereas $\delta^{13} \mathrm{C}$ and $\delta^{34} \mathrm{~S}$ provide information on the exploited foraging habitats, such as benthic/pelagic or marine/continental (Dufour and Gerdeaux, 2001), $\delta^{15} \mathrm{~N}$ has been widely used as a proxy for trophic level (Peterson and Fry, 1987). In addition, transforming isotopic information into dietary proportions of isotopically distinct dietary sources is now feasible through the use of multi-source isotope mixing models (Moreno et al., 2010; Phillips, 2001; Phillips and Koch, 2002; Phillips et al., 2009; Ramos et al., 2009b, 2011), which can provide more reliable information on trophic interaction.

The aim of this work was to evaluate the differential use of two marine habitats and landfill by a colony of YLGs breeding on Chikly Island: the Lake of Tunis, the Gulf of Tunis and landfill sites. Defining the importance of each habitat being exploited by a population is fundamental for wildlife management and conservation, since accessibility to trophic resources and their use plays a key role in survival and reproductive success. We therefore reconstructed the diet of the yellow-legged gull colony over three years by combining two complementary techniques: the analysis of regurgitates of fledglings and stable isotope analysis of their growing mantle feathers. To determine the contribution of each of the three foraging habitats to the diet of the colony and their variation over time, we applied a mixing model for each monitored year.

Although similar studies have been carried out on this species in the western Mediterranean (Moreno et al., 2010), this is the first study on the North African coast.
MATERIAL AND METHODS

\section{Study area}

A study of the yellow-legged gull population breeding on Chikly Island was carried out over three years (2005, 2006 and 2007). The island is in the northern part of the Lake of Tunis $\left(36^{\circ} 49^{\prime} \mathrm{N}, 10^{\circ} 13^{\prime} \mathrm{E}\right)$, a brackish urban lagoon surrounded by the capital city (fig. 1). The lake is divided into a northern and a southern part by a navigation channel. The Lake of Tunis has a well-known history of severe eutrophication with resulting anoxia and massive fish death, especially before the restoration work that was carried out in the mid-1980s (Harbridge et al., 1976; Mastouri and Brahim, 1996). The northern part, which covers an area of 2,480 ha, continues to suffer intense human pressure, as it is the subject of a growing urban development project. It also receives water inputs from several rainfallcollecting channels, as well as from the adjacent Gulf of Tunis. The Gulf of Tunis is part of the Mediterranean Sea, and extends over nearly $150 \mathrm{~km}$ between Cape Sidi Ali El Mekki and the northeastern tip of the Cap Bon peninsula $\left(37^{\circ} 0^{\prime} \mathrm{N}, 10^{\circ} 30^{\prime} \mathrm{E}\right)$. The Tunisian legislation on benthic fishing activities in the Gulf of Tunis is very strict as this area represents a nursery for several fish species. It is opened for only a few months per year depending on a decision taken yearly following studies of the status of fish stocks.

\section{Sample collection}

During the breeding periods of 2005, 2006 and 2007, we collected growing mantle feathers of 21,40 and 25 fledglings, respectively. Spontaneous fledgling regurgitates ( $\mathrm{N}=16,44$ and 11, in 2005, 2006 and 2007, respectively) were also collected, individually placed in sealed plastic bags and stored at $-20^{\circ} \mathrm{C}$ until laboratory analysis. Only one 

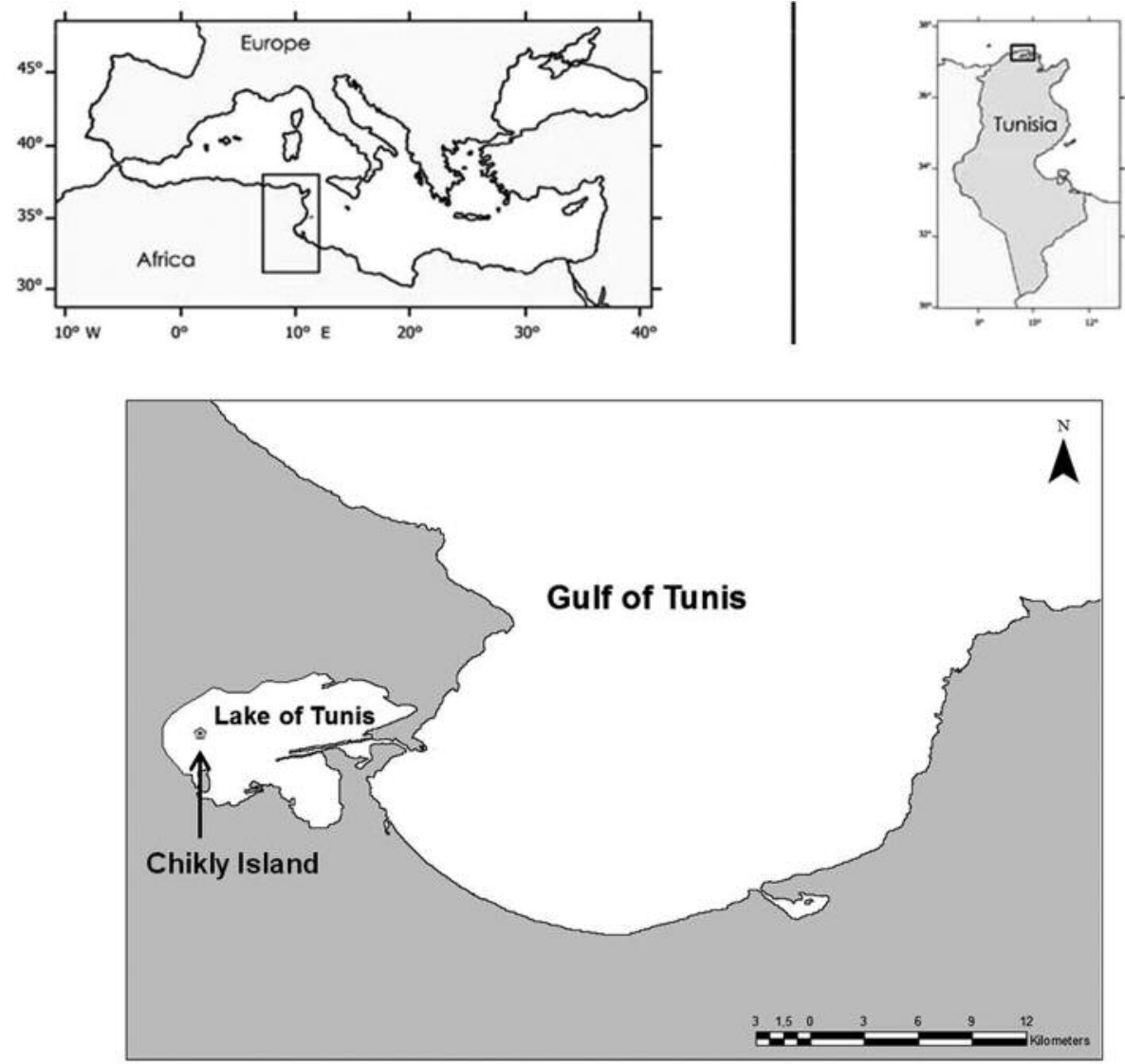

FIG. 1.-Study area showing the breeding colony of yellow-legged gulls on Chikly island and both marine foraging habitats: the Lake and Gulf of Tunis.

[Área del estudio en la que se muestra la colonia de cría de gaviota patiamarilla en la isla de Chikly, así como las áreas marinas de forrajeo: el lago y el golfo de Túnez.]

fledgling was sampled from each brood, to avoid pseudo-replication arising from parents feeding the same prey to all their offsprings.

\section{Analysis of regurgitates}

Regurgitate prey items were individually identified to taxonomic order level and weighed (wet weight). With the aim of estimating the contribution of the different foraging habitats to the chick's diet, food items were also classified according to their ecological categories: marine prey (including all fish and cuttlefish), landfill (including all kinds of domestic food), freshwater invertebrates, and terrestrial invertebrates. For each year and, in order to estimate the relative importance of each category, both prey biomass percentage $(\% \mathrm{~B})$ and numeric percentage $(\% \mathrm{~N})$ were estimated. 


\section{TABLE 1}

Taxonomic analysis of regurgitated prey and their numeric $(\% \mathrm{~N})$ and biomass percentage $(\% \mathrm{~B})$ in the diet of yellow-legged gulls from Chikly colony.

[Análisis taxonómico de las presas encontradas en los regurgitados, y sus importancias numéricas (\%N) y de biomasa $(\% B)$ en la dieta de las gaviotas patiamarillas en la colonia Chikly.]

\begin{tabular}{cccccc}
\hline Year & Index & Marine prey & Landfill & $\begin{array}{c}\text { Freshwater } \\
\text { invertebrate }\end{array}$ & $\begin{array}{c}\text { Terrestrial } \\
\text { invertebrate }\end{array}$ \\
\hline $\mathbf{2 0 0 5}$ & $\% \mathrm{~N}$ & $63.2 \%$ & $26.3 \%$ & $5.3 \%$ & $5.3 \%$ \\
\hline $\mathbf{2 0 0 6}$ & $\% \mathrm{~B}$ & $73.9 \%$ & $22.8 \%$ & $<0.01 \%$ & $3.3 \%$ \\
& $\% \mathrm{~N}$ & $75.9 \%$ & $18.5 \%$ & $5.6 \%$ & \\
\hline $\mathbf{2 0 0 7}$ & $\% \mathrm{~B}$ & $68.0 \%$ & $25.1 \%$ & $7.0 \%$ & \\
& $\% \mathrm{~N}$ & $83.3 \%$ & $16.7 \%$ & & \\
\hline
\end{tabular}

\section{Mixing model}

With the aim of estimating the relative importance of the different foraging habitats for gulls from the studied colony, we used a three-isotope approach $\left(\delta^{13} \mathrm{C}, \delta^{34} \mathrm{~S}\right.$ and $\left.\delta^{15} \mathrm{~N}\right)$, defining three endpoints: the Lake of Tunis, Gulf of Tunis and a terrestrial ecosystem. The last category was a source of mainly landfill items and terrestrial invertebrates. We did not consider freshwater invertebrates since they constituted a very small proportion in terms of both numeric and biomass percentage in the diet of the colony $(<0.01 \%)$.

The stable isotope signatures of the three foraging habitats (Gulf, Lake and terrestrial ecosystem) were estimated using the stable isotope signatures of all prey found in regurgitates collected in the three years of monitoring. As marine prey found in fledgling regurgitates could have come from either the Lake of Tunis or the Gulf of Tunis, we used our results from a previous study that allowed us to assign each prey item to its source based on its $\delta^{34} \mathrm{~S}$ (Abdennadher et al., 2011).
In order to ascertain the relative contribution of the different types of prey to the endpoint signature, we weighted prey isotope signatures and elemental concentrations by prey fresh biomass.

We used a Bayesian stable-isotope mixing model (SIAR), which allowed the inclusion of the isotopic signatures of the consumers, potential dietary resources, elemental concentrations and diet-tissue isotopic discrimination factors, along with the uncertainty of these values. We used means and standard deviations for all diet-tissue isotopic discrimination factors except for S. S is less commonly used than $\mathrm{C}$ and $\mathrm{N}$, and thus the literature did not provide an SD, so we took $\mathrm{SD}=0$ for the sulphur discrimination factor. The isotopic discrimination factors (mean \pm $\mathrm{SD}$ ) used in the model were obtained from the literature: $\Delta^{13} \mathrm{C}=1.15 \pm 0.18$ (Caut et al., 2009), $\Delta^{34} \mathrm{~S}=1.3$ (Ramos et al., 2009b; Peterson et al., 1987) and $\Delta^{15} \mathrm{~N}=2.91 \pm 0.16$ (Caut et al., 2009). Estimations were obtained using the SIAR package (Parnell et al., 2008) for R (http://r-project.org). 


\section{Stable isotope analysis}

Measurements of $\delta^{13} \mathrm{C}, \delta^{34} \mathrm{~S}$ and $\delta^{15} \mathrm{~N}$ of fledgling feathers were carried out during the three years. Feathers were initially washed in a $0.25 \mathrm{M}$ sodium hydroxide solution and rinsed thoroughly in distilled water to remove any surface contamination. Both feathers and prey were oven-dried at $60^{\circ} \mathrm{C}$ to constant weight and ground to a fine and homogeneous powder using an impactor mill (Freezer/mill6750 Spex Certiprep) that operates at liquid nitrogen temperature. In order to reduce variability due to differences in lipid content, individualised prey from regurgitates were treated wholly and subjected to lipid extraction by successive rinsing in a chloroform and methanol solution (2:1) (Folch et al., 1957; Logan et al., 2008). Sub-samples of the powdered feathers $(0.36 \mathrm{mg}$ for $\delta^{15} \mathrm{~N}$ and $\delta^{13} \mathrm{C} ; 3.6 \mathrm{mg}$ for $\delta^{34} \mathrm{~S}$ analyses) and prey $\left(0.5 \mathrm{mg}\right.$ for $\delta^{15} \mathrm{~N}$ and $\delta^{13} \mathrm{C} ; 8 \mathrm{mg}$ for $\delta^{34} \mathrm{~S}$ analyses) were packed in Sn capsules and combusted for isotopic determination by EAIRMS (Elemental Analysis-Isotope Ratio Mass Spectrometry) using a ThermoFinnigan Flash 1112 (for $\mathrm{N}$ and $\mathrm{C}$ )/1108 (for S) elemental analyser coupled to a Delta isotope ratio mass spectrometer via CONFLOIII interface (Servei Cientifico-Tècnics of the University of Barcelona). Stable isotope ratios were expressed in parts per thousand according to the conventional equation: $\delta \mathrm{X}(\%)=\left[\left(\mathrm{R}_{\text {Sample }} /\right.\right.$ $\left.\mathrm{R}_{\text {Standard }}\right)$ - 1] $* 1000$, where $\delta \mathrm{X}(\% 0)$ is $\delta^{13} \mathrm{C}$, $\delta^{15} \mathrm{~N}$ or $\delta^{34} \mathrm{~S}, \mathrm{R}_{\text {sample }}$ is the corresponding ratio of ${ }^{13} \mathrm{C} /{ }^{12} \mathrm{C},{ }^{15} \mathrm{~N} /{ }^{14} \mathrm{~N}$ or ${ }^{34} \mathrm{~S} /{ }^{32} \mathrm{~S}$ in the analysed tissue, and $\mathrm{R}_{\text {Standard }}$ is the corresponding ratio of ${ }^{13} \mathrm{C} /{ }^{12} \mathrm{C},{ }^{15} \mathrm{~N} /{ }^{14} \mathrm{~N}$ or ${ }^{34} \mathrm{~S} /{ }^{32} \mathrm{~S}$ related to the standard values. $\mathrm{R}_{\text {Standard }}$ values for $\delta^{13} \mathrm{C}, \delta^{15} \mathrm{~N}$ and $\delta^{34} \mathrm{~S}$ were those of Pee Dee Belemnite (PDB), atmospheric nitrogen (AIR) and Canyon Diablo Troilite (CDT), respectively. We used international standards (IAEA) in each batch of 12 samples to calibrate the system. Replicate assays of standard materials indicated standard deviations of $\pm 0.1 \%$ o, $\pm 0.2 \%$ ond $\pm 0.2 \%$, for carbon, sulphur and nitrogen, respectively.

\section{Statistical analysis}

Normality of the stable isotope signatures was visually checked using quantile plots. Comparison among years was done by means of one-way analysis of variance (ANOVA), with Welch correction when appropriate to account for variance heterogeneity. Post-hoc pairwise comparisons were performed by Tukey's or Tamhane's procedure, depending on whether or not the variances were homogeneous. Statistical analysis was carried out using SPSS 15.0.

\section{RESULTS}

\section{Analysis of regurgitates}

Identification of prey found in regurgitates showed that terrestrial invertebrates were only present in 2005. Freshwater invertebrates made a minor contribution to the colony diet, especially during 2005 , when their percentage of the biomass was very low $(\% \mathrm{~B}<0.01 \%)$.

Marine prey and landfill categories were the most recurrent and important in terms of both numeric and biomass indices (table 1). According to these indices, marine prey was the most important resource during the three years of the study.

\section{Mixing model}

Stable isotopes of prey, pooled together to calculate endpoint means, are presented in table 2. In order to disentangle the contribution of the two marine habitats together with the terrestrial ecosystem to the diet of the colony, we applied a three-isotope Bayesian Mixing Model. The mixing model showed, in accordance with the analysis of regurgitates, that regardless of the year considered, use of the terrestrial ecosystem was minor. The diet of the studied colony consisted mainly of marine prey from both the Lake of Tunis and the Gulf. In 2005, Gulf use 


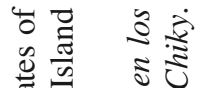

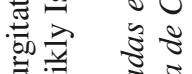

施

每 8

चี

言造施

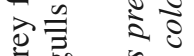

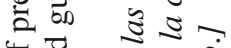

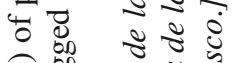

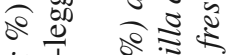

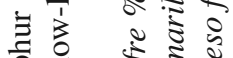

के

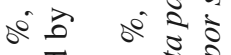

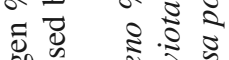

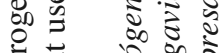

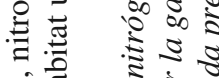

o.

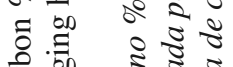

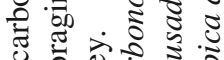

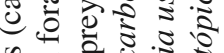

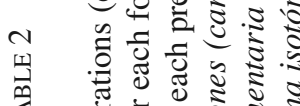

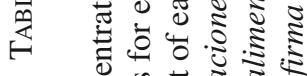

यु

ㄷำ

ป

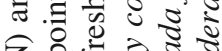

z

के एँ

की को

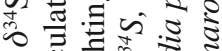

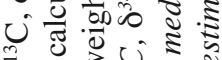

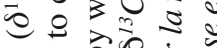

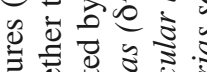

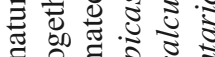

品. 0 .

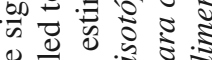

制

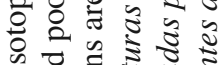

.

는

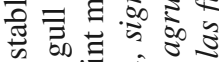

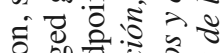

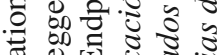

可

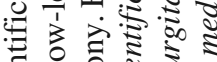

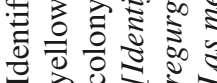

\begin{tabular}{|c|c|c|c|c|c|c|c|c|}
\hline 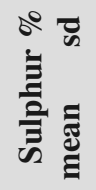 & $\begin{array}{l}\breve{0} \\
\stackrel{0}{0}: 0\end{array}$ & $\begin{array}{l}\breve{0} \quad \stackrel{0}{\circ} \stackrel{\infty}{0} \\
\stackrel{-}{\square}=\stackrel{\infty}{-} \stackrel{\infty}{-}\end{array}$ & 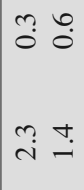 & 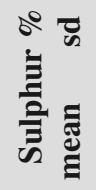 & $\stackrel{0}{0}$ & $\because$ & ?n & 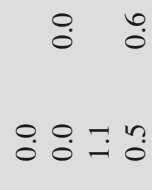 \\
\hline 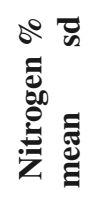 & $\begin{array}{l}\stackrel{0}{0} \\
\dot{\theta} \ddot{0}\end{array}$ & 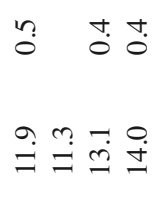 & 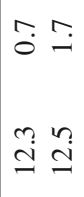 & 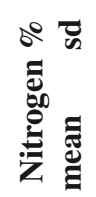 & $\ddot{n}$ & $\ddot{0}$ & $\stackrel{\varrho}{0}$ & 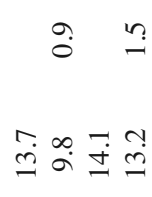 \\
\hline 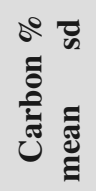 & 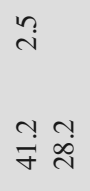 & 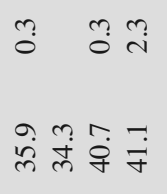 & 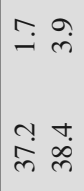 & 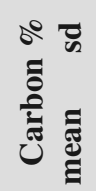 & $\overrightarrow{\dot{m}}$ & $\frac{n}{m}$ & t. & 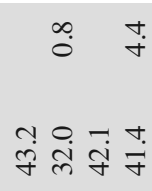 \\
\hline 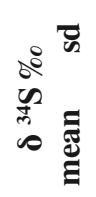 & 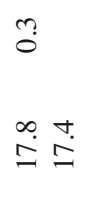 & 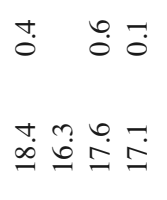 & 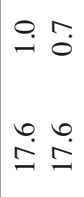 & 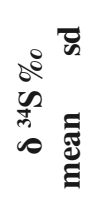 & 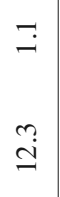 & $\stackrel{\infty}{\sim}$ & $\Xi$ & 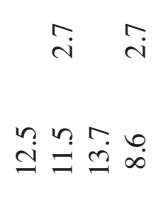 \\
\hline 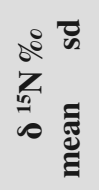 & $\begin{array}{l}\stackrel{0}{0} \\
\stackrel{\infty}{0} \stackrel{\infty}{\varrho}\end{array}$ & 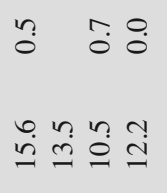 & 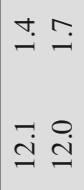 & 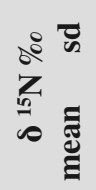 & $\stackrel{\infty}{\stackrel{\sim}{\sigma}}$ & $\begin{array}{l}0 \\
\ddot{g}\end{array}$ & $\stackrel{\text { Y }}{ \pm}$ & $\begin{array}{c}\stackrel{\infty}{i} \stackrel{0}{-} \\
\stackrel{\infty}{\infty} \stackrel{m}{=} \underset{m}{=}\end{array}$ \\
\hline 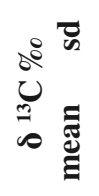 & 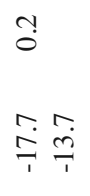 & 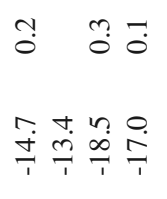 & 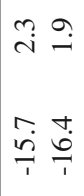 & 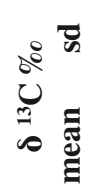 & $\begin{array}{l}\stackrel{0}{-} \\
\stackrel{n}{+} \\
\stackrel{n}{1}\end{array}$ & $\stackrel{\overbrace{}}{\stackrel{1}{1}}$ & $\frac{-}{\infty}$ & 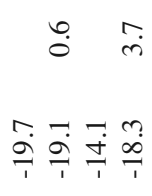 \\
\hline $\mathbf{z}$ & $n-$ & $n-0$ & $\theta$ & Z & N & - & $r$ & $-a-I$ \\
\hline 造 & 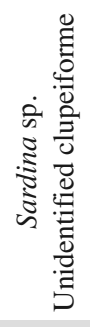 & 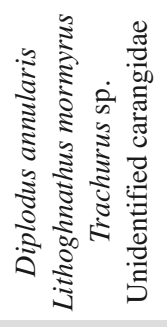 & 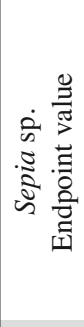 & $\frac{\mathscr{e}}{\tilde{\mathscr{E}}}$ & 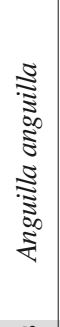 & 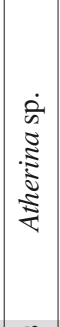 & 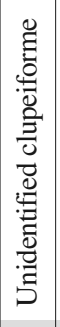 & 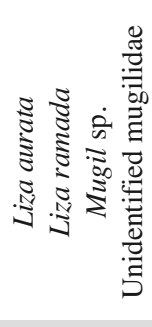 \\
\hline 瓷 & 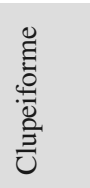 & 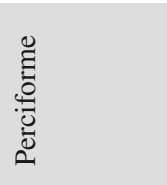 & $\begin{array}{l}\frac{\pi}{0} \\
: 0 \\
0 \\
0 \\
0\end{array}$ & 结 & 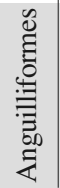 & 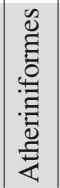 & 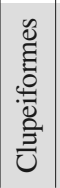 & 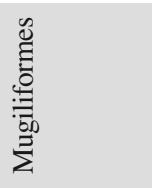 \\
\hline
\end{tabular}




\begin{tabular}{|c|c|c|c|c|c|c|}
\hline 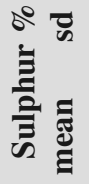 & 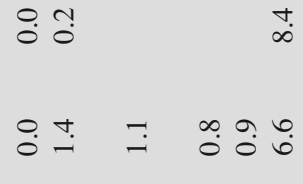 & $\stackrel{\circ}{0}$ & $\begin{array}{l}\stackrel{9}{-} \stackrel{9}{-} \\
\text { 운 }\end{array}$ & 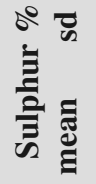 & $\stackrel{+}{\circ}$ & 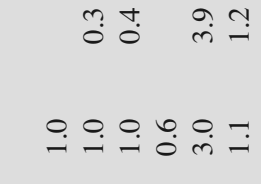 \\
\hline 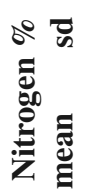 & 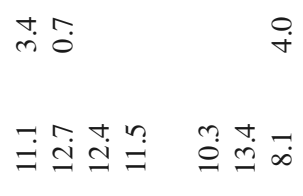 & $\stackrel{2}{r}$ & $\begin{array}{l}\stackrel{\infty}{\rightarrow} \stackrel{\infty}{i} \\
\stackrel{0}{0} \stackrel{0}{=}\end{array}$ & 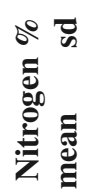 & $\stackrel{t}{n}$ & 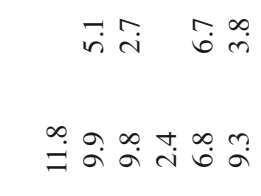 \\
\hline 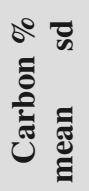 & 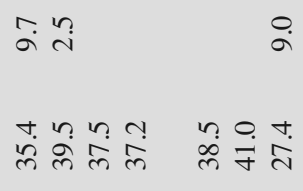 & $\stackrel{\sim}{\sim}$ & 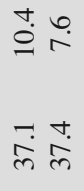 & 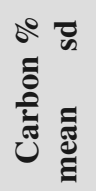 & $\begin{array}{l}\text { nु. } \\
\vec{n}\end{array}$ & 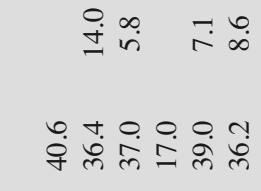 \\
\hline 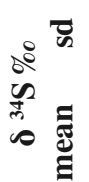 & 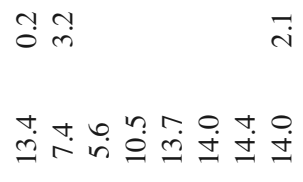 & $\stackrel{g}{\dot{I}}$ & 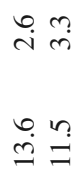 & 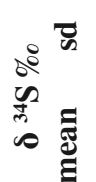 & $\tilde{i}$ & 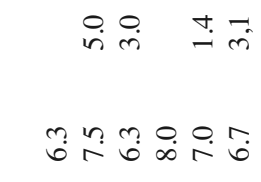 \\
\hline 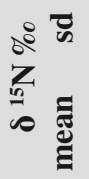 & 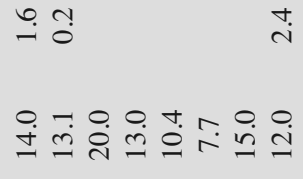 & $\stackrel{\Upsilon}{=}$ & 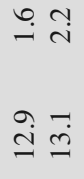 & 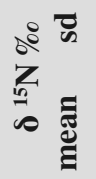 & $\stackrel{m}{i}$ & 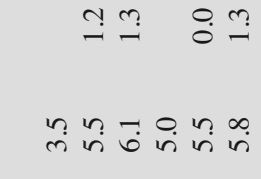 \\
\hline 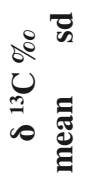 & 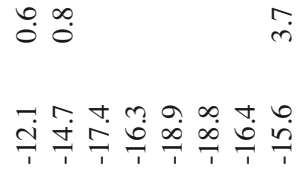 & $\begin{array}{l}\text { no } \\
\frac{1}{1}\end{array}$ & 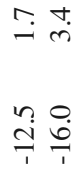 & 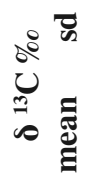 & $\begin{array}{l}\stackrel{0}{n} \\
\cdots \\
\cdots \\
\infty\end{array}$ & 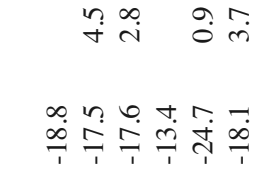 \\
\hline Z & $\mathrm{N}-\longrightarrow \rightarrow-\mathrm{N}$ & - & 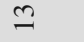 & Z & $\nabla$ & $-+I-N$ \\
\hline 逆 & 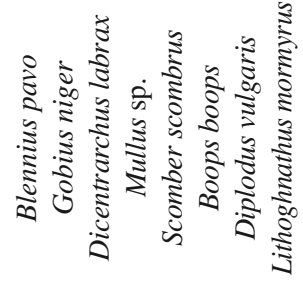 & 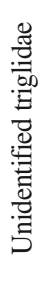 & 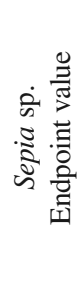 & $\frac{\mathscr{n}}{\mathscr{0}}$ & 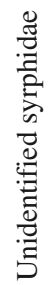 & 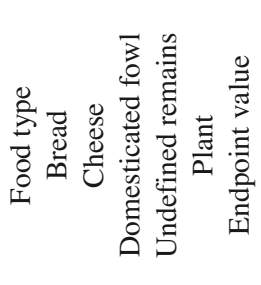 \\
\hline 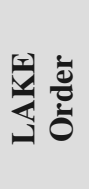 & 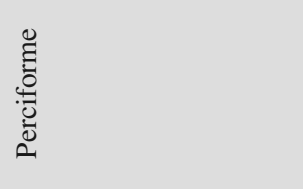 & 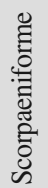 & $\begin{array}{l}\frac{\pi}{0} \\
: \overline{0} \\
\text { हn }\end{array}$ & 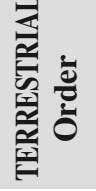 & 莺 & $\begin{array}{l}0 \\
\sum_{0} \\
\approx\end{array}$ \\
\hline
\end{tabular}


was at its minimum, and use of the terrestrial resource peaked, in comparison with 2006 and 2007. The contribution of the terrestrial resource varied between $29.5 \%$ (in 2006) and $49.3 \%$ (in 2005). In 2006, the most exploited feeding habitat was the Lake of Tunis and the less used was the Gulf. The Lake of Tunis was the most important foraging habitat used by the yellow-legged gull colony during the three years of the study. The contributions of the various sources and their $95 \%$ credibility intervals are shown in figure 2.
Stable isotope analysis of fledgling feathers

The isotopic composition of fledgling feathers showed a normal distribution in each of the three years of the study. $\delta^{15} \mathrm{~N}$ showed no significant difference among years $\left(\delta^{15} \mathrm{~N}\right.$ : $\left.\mathrm{F}_{283}=3.24, P=0.72\right)$. On the contrary, $\delta^{13} \mathrm{C}$ and $\delta^{34} \mathrm{~S}$ showed a slight increase between 2005 and $2006\left(\delta^{13} \mathrm{C}: \mathrm{F}_{2,83}=5.4, P=0.006\right.$; $\left.\delta^{34} \mathrm{~S}: \mathrm{F}_{2,81}=4.5, P=0.014\right)$, whereas homogeneous mean values were found in the 2006 and 2007 breeding seasons (fig. 3).
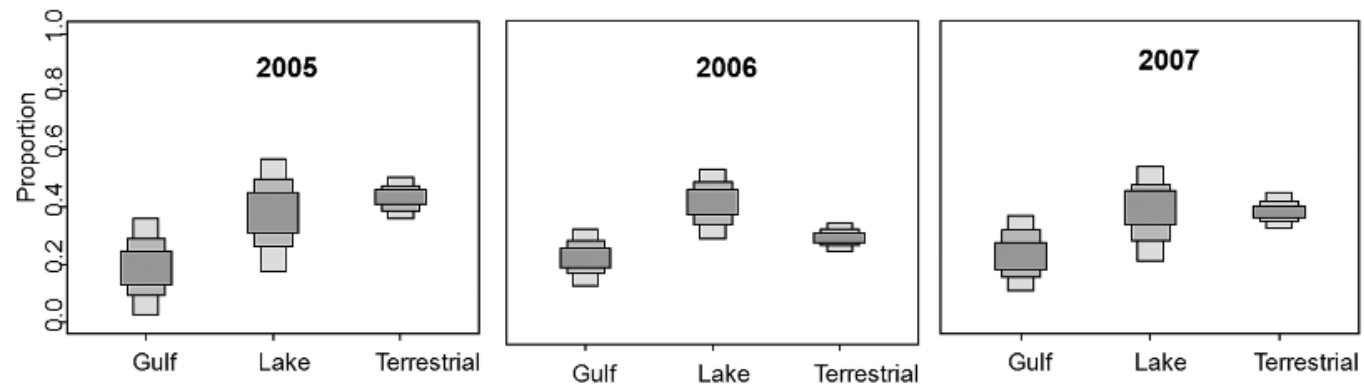

FIG. 2.-Contributions of the different foraging habitats to yellow-legged gull diet provided by the Bayesian mixing model with $95 \%, 75 \%$ and $50 \%$ credibility intervals.

[Diagrama de cajas generado por el SIAR revelando las contribuciones (\%) de las diferentes fuentes de alimentación en la dieta de la gaviota patiamarilla proporcionadas por el modelo de mezcla bayesiano, con intervalos de credibilidad al 95\%, $75 \%$ y 50\%.]
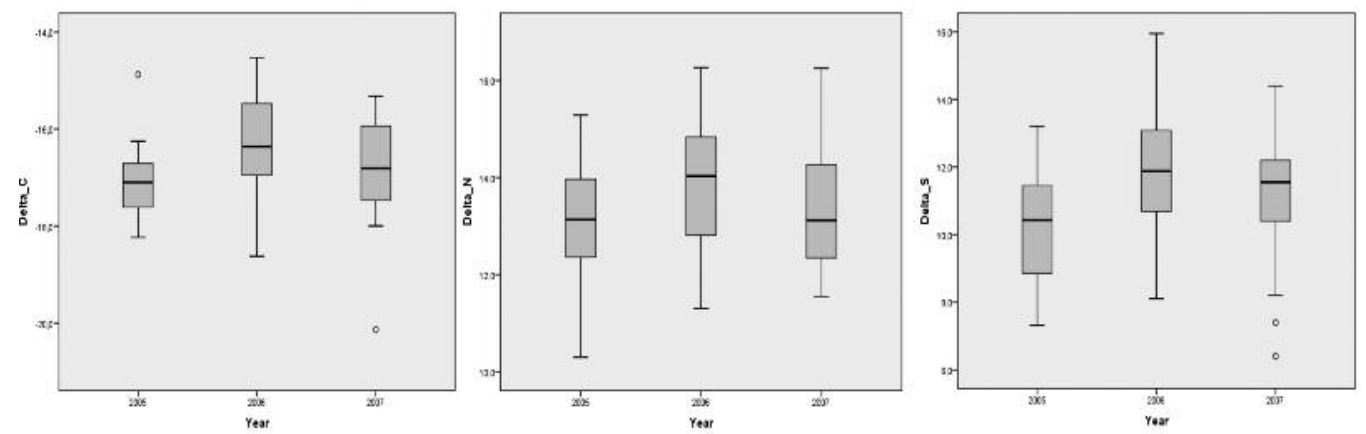

FIG. 3.-Isotopic signatures of fledgling feathers $\left(\delta^{13} \mathrm{C}, \delta^{34} \mathrm{~S}, \delta^{15} \mathrm{~N}\right)$ from the colony of yellow-legged gulls breeding on Chikly in 2005, 2006 and 2007.

[Signaturas isotópicas (medias y desviaciones estándares, con intervalos de confianza al 95\%) de las plumas de pollos $\left(\delta^{13} \mathrm{C}, \delta^{34} \mathrm{~S}, \mathrm{\delta}^{15} \mathrm{~N}\right)$ de la colonia de cría de gaviota patiamarilla en Chikly durante 2005, 2006 y 2007.] 


\section{DISCUSSION}

During the three years of the study, fledgling feathers showed a slight but significant increase in isotopic signatures of carbon and sulphur between 2005 and 2006, pointing to an increased consumption of marine resources $\left(\delta^{34} S\right)$ and a greater use of benthic resources $\left(\delta^{13} \mathrm{C}\right)$ in 2006 (Newsome et al., 2007). This change from one year to another could be explained by a change in prey availability, probably related to fishery activity. The yellow-legged gull is well known for its opportunistic behaviour and ability to adapt its diet to the most readily available resource (Duhem et al., 2007; González-Solís et al., 1997; Moulai, 2008; Oro et al., 1995). Even if yellow-legged gulls used the available resources differently during the three years of monitoring, no variation was detected in $\delta^{15} \mathrm{~N}$.

The analysis of prey from regurgitates showed that marine prey consumed by the gulls from the studied colony could have come from the Gulf or the Lake of Tunis. In addition, the analysis of regurgitates showed that these two food sources were used fairly constantly over the three years, whereas terrestrial and freshwater invertebrates were accessory resources, consumed only occasionally. The importance of this prey appeared when looking at numeric $(\% \mathrm{~N})$ or biomass percentages $(\% \mathrm{~B})$ of invertebrates: whereas \% $\mathrm{B}$ indicated a small contribution of invertebrates to the colony diet, the $\% \mathrm{~N}$ was higher.

Knowing the isotopic signatures associated with the main foraging habitats used by this generalist consumer, a three-isotope Bayesian mixing model allowed us to ascertain the quantitative importance of the different food sources available to the colony (Caut et al., 2009; Ramos et al., 2009b). In agreement with the conventional approach (analysis of regurgitates), the isotopic analysis suggested that marine prey was the most important food resource of the colony. The mixing model also allowed us to know that marine prey consumed by the colony during the monitoring period came mostly from the nearest aquatic habitat, the Lake of Tunis. Despite the availability of several open air dumps, yellow-legged gulls from the Chikly colony seem to be mainly marine foragers, in contrast with other studies (Arizaga et al., 2013; Bosch et al., 1994; Moreno et al., 2010). In other Mediterranean areas chicks are described as extremely dependent on open-air rubbish dumps (Duhem et al., 2007, 2008; Ramos et al., 2009a). The dietary contribution of marine prey (Lake and Gulf together) was major throughout the three years of the study, while the contribution of food of terrestrial origin was far less.

Combining conventional methods with stable isotope analysis provided an integrated view of the diet of the studied colony. While isotopic signatures yield data about assimilated food, analysis of regurgitates only gives information about ingested food. In addition, stable isotope analysis provided information about the foraging habitat exploited which, when integrated into a mixing model, allowed us to define the importance of each of the available food sources. Mixing models are widely used to provide quantitative indices of food source contributions to a diet (Moreno et al., 2010; Phillips and Koch, 2002). They require prior conventional diet analysis for a more informed selection of data for input into the mixing model. As the colony has two marine foraging habitats available, the isotopic discrimination between prey from the Lake or the Gulf (Abdennadher et al., 2011) was very helpful in estimating the importance of each one, which would have been impossible based on taxonomic data alone. The simultaneous use of three isotopes in a Bayesian SIAR mixing model showed a high 
discriminatory power for the study of a generalist forager like the yellow-legged gull. Another study has compared results from a Bayesian mixing model and an isosource mixing model and has shown that the former is more appropriate for the study of a generalist diet (Moreno et al., 2010). From a conservation perspective, knowing the main food source of the colony is essential for decision-making and environmental management. An isotopic approach has proven to be a useful tool for evaluating temporal variation in the feeding ecology of populations, and may become extremely useful for the management and conservation of wild species.

In summary, the analysis of regurgitates was the most effective for taxonomic identification but did not yield information about which foraging habitat was more exploited. In contrast, the isotopic approach enabled us to identify changes in the colony's use of feeding resources over time. The mixing model showed that the Lake of Tunis was the most important source of marine prey for the studied colony, whose trophic ecology could therefore be negatively affected by any environmental disturbance of this habitat. The coupling of the two techniques has resulted in a valuable contribution to understanding the trophic ecology of the yellow-legged gull. The data obtained may be useful in preven-ting any human disturbance or modification of the feeding habitats exploited by the colony, particularly since its breeding area on Chikly Island is submitted to such intense anthropogenic pressure.

ACKNOWLEDGEMENTS. - This paper was supported by a MAEC-AECI grant to Aida Abdennadher. Funds were provided by AECI-PCI Spanish-Tunisian projects A/2907/05 and A/6165/06 and project CGL 254 2008-05448C02-01 (MICIN, Spain).

\section{BIBLIOGRAPHY}

Abdennadher, A., Ramírez, F., Romdhane, M. S., Ruiz, X., Jover, L. and SANPera, C. 2011. Biomonitoring of coastal areas in Tunisia: Stable isotopes and trace elements analysis in the yellow-legged gull. Marine Pollution Bulletin, 60: 440-447.

Arizaga, J., Jover, L., Aldalur, A., Cuadrado, J. F., Herrero, A. and Sanpera, C. 2013. Trophic ecology of a resident yellow-legged gull (Larus michahellis) population in the Bay of Biscay. Marine Environmental Research, 8788: 19-25.

Bearhop, S., Adams, C. E., Waldron, S., Fuller, R. A. and Macleod, H. 2004. Determining trophic niche width: A novel approach using stable isotope analysis. Journal of Animal Ecology, 73: 1007-1012.

Bosch, M., Oro, D. and RuIZ, X. 1994. Dependence of yellow-legged gulls (Larus cachinnans) on food from human activity in two western Mediterranean colonies. Avocetta, 18: 135-139.

Caut, S., Angulo, E. and Courchamp, F. 2009. Variation in discrimination factors $\left(\Delta^{15} \mathrm{~N}\right.$ and $\Delta^{13} \mathrm{C}$ ): The effect of diet isotopic values and applications for diet reconstruction The Journal of Applied Ecology, 46: 443-453.

Cherel, Y., Hobson, K. A. and Weimerskirch, H. 2005. Using stable isotopes to study resource acquisition and allocation in procellariiform seabirds. Oecologia, 145: 533-540.

DuFFY, D. C. and JACKSON, S. 1986. Diet studies of seabirds: A review of methods. Colonial Waterbirds, 9: 1-17.

Dufour, E. and Gerdeaux, D. 2001. Apports des isotopes stables $(13 \mathrm{C} / 12 \mathrm{C}, 15 \mathrm{~N} / 14 \mathrm{~N}, 18 \mathrm{O} / 16 \mathrm{O}$, $36 \mathrm{~S} / 34 \mathrm{~S}, 87 \mathrm{Sr} / 86 \mathrm{Sr}$ ) aux études écologiques sur les poissons. Cybium, 25: 369-382.

Duhem, C., Roche, P., Vidal, E. and Tatoni, T. 2007. Distribution of breeding sites and food constrains size and density of yellow-legged gull colonies. Écoscience, 14: 535-543.

Duhem, C., Roche, P., Vidal, E. and Tatoni, T. 2008. Effects of anthropogenic food resources on yellow-legged gull colony size on Mediterranean islands. Population Ecology, 50: 91-100.

EINODER, L. D. 2009. A review of the use of seabirds as indicators in fisheries and ecosystem management. Fisheries Research, 95: 6-13. 
Finney, S. K., Wanless, S., Harris, M. P. and Monaghan, P. 2001. The impact of gulls on puffin reproductive performance: An experimental test of two management strategies. Biological Conservation, 98: 159-165.

Folch, J., LeEs, M. and Stanley, G. H. 1957. A simple method for the isolation and purification of total lipids from animal tissues. The Journal of Biological Chemistry, 226: 226-497.

GonzÁlez-Solís, J., Oro, D., Jover, L., Ruiz, X. and PEDROCCHI, V. 1997. Trophic niche width and overlap of two sympatric gulls in the southwestern Mediterranean. Oecologia, 112: 75-80.

González-Solís, J., Oro, D., Pedrocchi, V., Jover, L. and RuIZ, X. 1997. Bias associated with diet samples in Audouin's gulls. Condor, 99: 773-779.

Harbridge, W., Pilkey, O. H., Whaling, P. and Swetland, P. 1976. Sedimentation in the Lake of Tunis: A lagoon strongly influenced by man. Environmental Geology, 1: 215-225.

Hobson, K. A. and Cherel, Y. 2006. Isotopic reconstruction of marine food webs using cephalopod beaks: New insight from captively raised Sepia officinalis. Canadian Journal of Zoology, 84: 766-770.

Hobson, K. A., Piatt, J. F. and Pitocchelli, J. 1994. Using stable isotopes to determine seabird trophic relationships. Journal of Animal Ecology, 63: 786-798.

Logan, J. M., JARDine, T. D., Miller, T. J., BunN, S. E., Cunjak, R. A. and Lutcavage, M. E. 2008. Lipid corrections in carbon and nitrogen stable isotope analyses: Comparison of chemical extraction and modelling methods. Journal of Animal Ecology, 77: 838-846.

Mastouri, A. and Brahim, M. 1996. Lac Sud de Tunis: Vulnérabilité hydrobiologique et sédimentologie. Bulletin de l'Institut National des Sciences et Technologie de la Mer, 8: 5-33.

Moreno, R., Jover, L., Ruiz, X., Munilla, I., Velando, A. and SANPERA, C. 2010. A threeisotope approach to disentangling the diet of a generalist consumer: The yellow-legged gull in northwest Spain. Marine Biology, 157: 545-553.

MoulaI, R. 2008. Impact of refuse dump on the diet of the yellow-legged gull Larus michaellis in the bejaia area (Algeria). Revue d'Écologie, 63: 239-250

Newsome, S. D., Martínez del Río, C., Bearhop, S. and PHILLIPS, D. L. 2007. A niche for isotopic ecology. Frontiers in Ecology and the Environment, 5: 429-436.

Oro, D., Bosch, M. and RuIz, X. 1995. Effects of a trawling moratorium on the breeding success of the yellow-legged gull Larus cachinnans. Ibis, 137: 547-549.

PARNELl, A., INGER, R., BEARHOP, S. and JACKSON, A. L. 2008. Stable Isotope Analysis in R (SIAR). http://cran.r-

project.org/web/packages/siar/index.html (Accessed on 29 May 2014).

Peterson, B. J. and Fry, B. 1987. Stable isotopes in ecosystem studies. Annual Review of Ecology and Systematics, 18: 293-320.

Peterson, B. J. and Howarth, R. W. 1987. Sulfur, carbon, and nitrogen isotopes used to trace organic matter flow in the salt-marsh estuaries of Sapelo Island, Georgia. Limnology and oceanography, 32: 1195-1213.

PHILlIPS, D. L. 2001. Mixing models in analyses of diet using multiple stable isotopes: A critique. Oecologia, 127: 166-170.

Phillips, D. L. and KocH, P. L. 2002. Incorporating concentration dependence in stable isotope mixing models. Oecologia, 130: 114125.

PhILliPs, R., BEARHOP, S., MCGILl, R. and DAWSON, D. 2009. Stable isotopes reveal individual variation in migration strategies and habitat preferences in a suite of seabirds during the nonbreeding period. Oecologia, 160: 795-806.

Ramos, R., RAmírez, F., CARrasco, J. L. and JOVER, L. 2011. Insights into the spatiotemporal component of feeding ecology: An isotopic approach for conservation management sciences. Diversity and Distributions, 17: 338349.

Ramos, R., Ramírez, F., SAnPera, C., Jover, L. and RuIZ, X. 2009a. Diet of yellow-legged gull Larus michahellis chicks along the Spanish western Mediterranean coast: The relevance of refuse dumps. Journal of Ornithology, 150: 265-272.

Ramos, R., Ramírez, F., SANPera, C., Jover, L. and RuIz, X. 2009b. Feeding ecology of yellowlegged gulls Larus michahellis in the western Mediterranean: A comparative assessment using conventional and isotopic methods. Marine Ecology Progress Series, 377: 289-297.

Sorace, A. and Gustin, M. 2009. Distribution of generalist and specialist predators along urban 
gradients. Landscape and Urban Planning, 90: 111-118.

Thibault, J., Zotier, R., Guyot, I. and Bretagnolle, V. 1996. Recent trends in breeding marine birds of the Mediterranean region with special reference to Corsica. Colonial Waterbirds, 19: 31-40.

Vidal, E., Medail, F. and TAtoni, T. 1998. Is the yellow-legged gull a superabundant bird species in the Mediterranean? Impact on fauna and flora, conservation measures and research priorities. Biodiversity Conservation, 7: 1013-1026.
Votier, S. C., Bearhop, S., MacCormick, A., RatclifFe, N. and Furness, R. W. 2003. Assessing the diet of great skuas, Catharacya skua, using five different techniques. Polar Biology, 26: 20-26.

Received: 26 December 2013 Accepted: 9 August 2014

Editor: Rodrigo Vásquez 